\section{(6) OPEN ACCESS}

\title{
Haemophagocytic lymphohistiocytosis associated with fulminant hepatitis and multiorgan failure following primary Epstein-Barr virus and herpes simplex virus type 1 infection
}

\author{
Claudia Honsig, ${ }^{1}$ Sandra Beinhardt, ${ }^{2}$ Josef Tomasits, $^{3}$ Hans Peter Dienes ${ }^{4}$
}

\begin{abstract}
${ }^{1}$ Division of Clinical Virology, Department of Laboratory Medicine, Medical University of Vienna, Vienna, Austria ${ }^{2}$ Department of Internal Medicine III, Medical University of Vienna, Vienna, Austria ${ }^{3}$ Kepler Universityclinic, Med Campus III, Linz, Austria ${ }^{4}$ Medical University of Vienna, Institute of Clinical Pathology, Vienna, Austria
\end{abstract}

\section{Correspondence to} Dr Claudia Honsig, claudia.honsig@meduniwien. ac.at

Accepted 17 January 2017
CrossMark

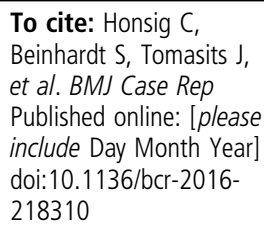

\section{SUMMARY}

We present a case of severe fatal hepatitis in a young patient presumably triggered by two ubiquitous viral diseases which occurred in close succession. This case is unusual because of the exceptional chronological sequence of primary Epstein-Barr virus and herpes simplex virus type 1 infection causing systemic immune dysregulation associated with rapidly developing liver failure and consecutive multiorgan failure. Clinical, laboratory and histopathological findings indicated the development of secondary haemophagocytic

lymphohistiocytosis triggered by these closely succeeding viral primary infections.

\section{BACKGROUND}

Haemophagocytic lymphohistiocytosis (HLH) is a potentially fatal syndrome characterised by an uncontrolled hyperinflammatory response with heterogeneous aetiology. ${ }^{1}{ }^{2}$ HLH is categorised as primary HLH (or familial HLH) in patients with underlying genetic causes and as secondary HLH (SHLH) when family history or known genetic causes are absent. SHLH is associated with a wide spectrum of underlying conditions: viral infections have been reported as the most common triggers (29\%), followed by other infections, malignancies, autoimmune disorders and immune suppression. ${ }^{1}$ Among viral infections, Epstein-Barr virus (EBV) has been described as the most frequent virus that associates with SHLH, herpes simplex virus 1 as the next most common virus. ${ }^{3-6}$ In healthy, immunocompetent persons at any age, EBV and herpes simplex virus (HSV) infection are usually self-limiting, rarely lead to complications and are both uncommon causes of acute liver failure (ALF). ${ }^{7-11}$ The case presented in this report highlights the possibility of a synergistic effect of these two closely succeeding viral primary infections in the development of a severe systemic disease in an immunocompetent person. In addition, it emphasises that SHLH should be suspected routinely when severe systemic illness with multiorgan failure develops following a viral infection and that the diagnosis should be confirmed rapidly by laboratory and histopathological investigations. In addition to suppression of the severe hyperinflammation which is the main therapeutic aim in HLH, early diagnosis and treatment of the potential underlying disease may also influence the clinical outcome. ${ }^{12}$

\section{CASE PRESENTATION}

A 21-year-old patient presented at a peripheral hospital with a protracted febrile urinary tract infection. The patient did not have any significant medical history, and on admission physical examination was normal. Mild thrombocytopenia and elevated liver enzymes were explained by the serological diagnosis of primary EBV infection.

MRI of the kidneys revealed no abnormalities, however, splenomegaly and multiple, smallest, inconclusive hepatic lesions were detected. Owing to the inconclusive MRI of the liver, the antibiotic therapy was stopped immediately and paracetamol was replaced by metamizole. Neither microbiological urine culture nor blood culture revealed a causative microorganism.

By day 4 after admission the liver function had decreased dramatically and ALF followed by acute renal failure developed. Leucopenia, thrombopenia and a significantly elevated ferritin level indicated the beginning of severe immune dysregulation (table 1). The patient was transferred to the University Hospital Vienna where on admission genital lesions suggestive of HSV infection were detected and intravenous acyclovir was started immediately. Within only a few hours, the patient's condition rapidly deteriorated, the patient developed multiorgan failure and died-despite intensive care treatment-only 6 days after the initial admission to hospital.

In a serum sample taken on day 5, EBV DNA was detected by PCR and primary EBV infection was again confirmed by serology, as VCA IgM antibodies and VCA IgG antibodies of low avidity were detected. In addition, HSV1 PCR was also highly positive in this serum sample and the detection of HSV IgG antibody seroconversion confirmed additional primary infection with HSV1 (table 1).

As expected, postmortem analysis of small tissue samples of liver, spleen, kidney and gallbladder by PCR revealed HSV1 and EBV DNA in all of the samples. Particularly high concentrations of HSV1 DNA were detected in liver and spleen tissues (8.40E +06 and $7.20 \mathrm{E}+06$ copies/mg, respectively). EBV DNA concentration in these tissues was $1.76 \mathrm{E}$ +03 copies $/ \mathrm{mg}$ (liver) and $7.60 \mathrm{E}+04$ copies/mg (spleen). 
Table 1 Course of laboratory and virological findings during hospital stay

\begin{tabular}{|c|c|c|c|c|c|}
\hline Day of hospitalisation & 1 & 3 & 4 & 5 & 6 \\
\hline ALT (U/L) & 375 & 822 & 1213 & 1831 & 2650 \\
\hline AST (U/L) & 475 & 1929 & 3387 & 6319 & 11150 \\
\hline$\gamma \mathrm{GT}(\mathrm{U} / \mathrm{L})$ & 198 & 230 & 248 & 336 & 326 \\
\hline ALP (U/L) & & 263 & 352 & 570 & 648 \\
\hline Total bilirubin (mg/dL) & & & 1.9 & 3.1 & 4.32 \\
\hline Ferritin (ng/mL) & & 1844 & & 7058 & \\
\hline Creatinine (mg/dL) & 0.8 & 0.9 & & 2.5 & 4.01 \\
\hline WCC (G/L) & 11.2 & 6.32 & 4.29 & & 1.52 \\
\hline $\mathrm{HgB}(\mathrm{g} / \mathrm{dL})$ & 12 & 11,5 & 10.5 & & 6.5 \\
\hline Platelet (G/L) & 130 & 122 & 113 & & 23 \\
\hline sCD25 (U/mL) & & & & & 338.6 \\
\hline HSV-1 (cp/mL serum) & & $1.48 \mathrm{E}+07$ & & $1.88 \mathrm{E}+08$ & \\
\hline Anti-HSV IgM & & Negative & & Negative & \\
\hline Anti-HSV IgG & & Negative & & Borderline/positive & \\
\hline EBV (cp/mL serum) & & $1.77 \mathrm{E}+04$ & & $2.14 \mathrm{E}+04$ & \\
\hline Anti-EBV VCA IgM & & Positive & & Positive & \\
\hline Anti-EBV VCA IgG & & Positive & & Positive & \\
\hline Anti-EBV VCA IgG avidity & & & & Low & \\
\hline Anti-EBV EBNA1 & & Negative & & Borderline/negative & \\
\hline
\end{tabular}

ALP, alkaline phosphatase; ALT, alanine transaminase; AST, aspartate transaminase; EBNA, Epstein-Barr virus nuclear antigen 1; EBV, Epstein-Barr virus; HgB, haemoglobin; HSV, Herpes Simplex virus type 1; IgG, immunoglobulin G; IgM, immunoglobulin M; VCA, viral capsid antigen; WCC, white cell count; $\gamma \mathrm{GT}, \gamma$-glutamyltransferase.

Figure 1 (A) Large confluent areas of necrosis without zonal binding (H\&E staining, $\times 60$ ). (B) In the margin of the necrosis, hepatocytes display nuclei with typical viral inclusions (arrow). The necroinflammatory infiltrate consists of lymphocytes and a lot of polymorph nuclear leucocytes (H\&E staining, $\times 400)$. (C) HSV1-infected hepatocytes detected with immunoperoxidase staining $(\times 240)$. (D) In some areas of the liver, typical features of EBV hepatitis with abundant lymphocytic infiltrates in the sinusoids were still present (H\&E staining, $\times 240$ ). (E) EBV LMP1 detected by immunostaining with alkaline phosphatase, $\times 240$ (arrow). (F) After extraction of EBV DNA and subsequent $P C R$, viral DNA could be demonstrated. ( $a$ and f) DNA ladder; (b) empty; (c) patient; (d) negative control; (e) positive control.
A

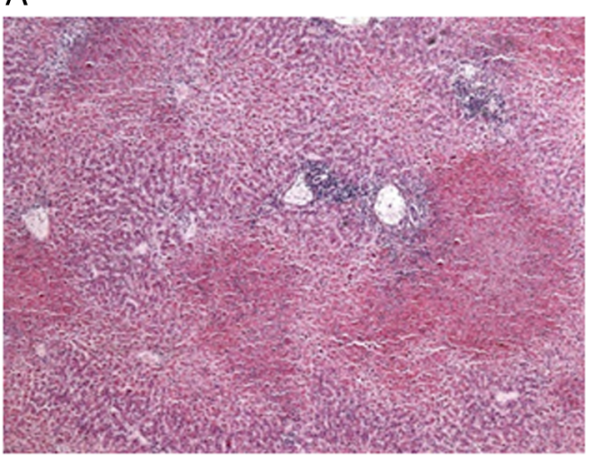

C

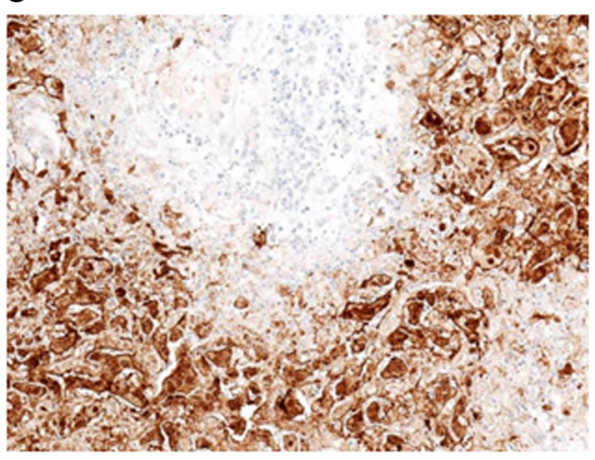

E
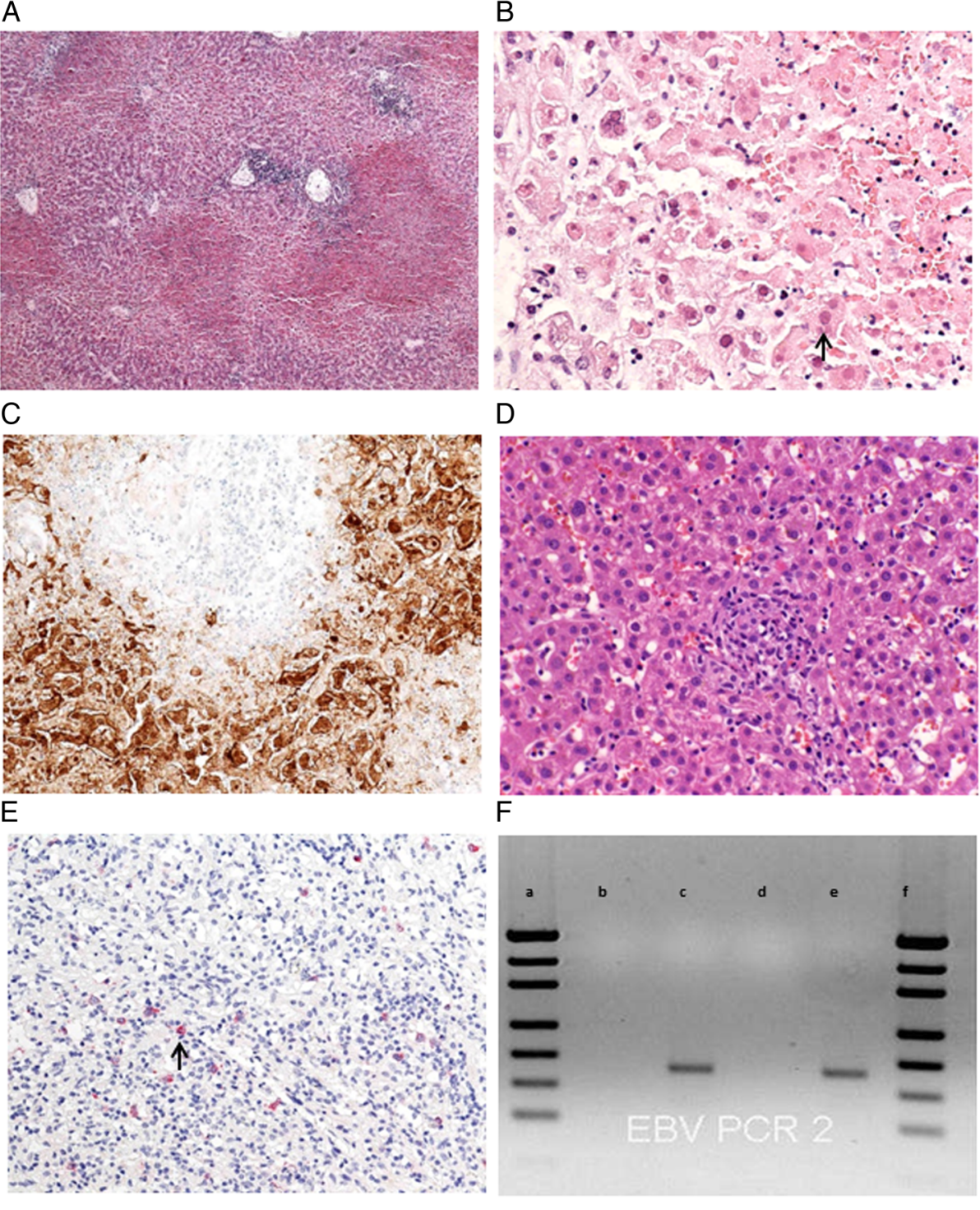

D

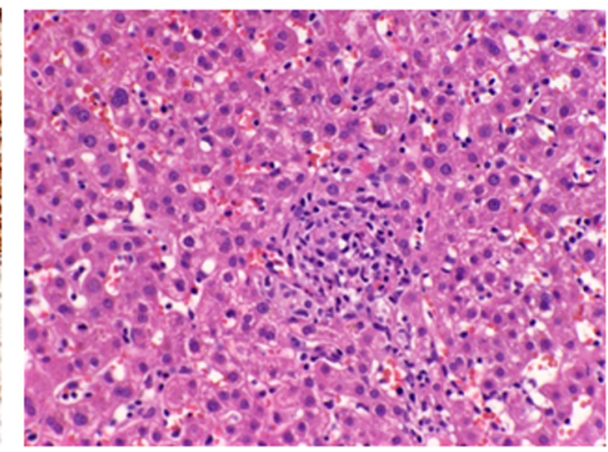

$\mathrm{F}$ 
Histopathology of the postmortem liver samples displayed the typical necrosis pattern of HSV hepatitis with confluent necroses in a geographical pattern without zonal binding (figure 1A) and a mixed reactive inflammatory infiltrate including a substantial number of polymorph nuclear leucocytes (figure 1B). Hepatocytes showed typical nuclear inclusions with the virus (figure 1B). Immunoperoxidase staining confirmed the diagnosis of HSV1 hepatitis (figure 1C). In some areas, the characteristic features of EBV-hepatitis could still be found (figure 1D). The diagnosis was confirmed by the detection of EBV LMP1 by alkaline phosphatase staining (figure 1E) and the detection of EBV by PCR after extraction of EBV DNA from the liver tissue (figure $1 \mathrm{~F}$ ). In portal macrophages, a trapping of erythrocytes was found and in the sinusoids the activated Kupffer cells showed a conspicuous erythrophagocytosis, consistent with SHLH (figure 2).

These characteristic histopathological changes in liver tissue along with the laboratory and clinical findings indicated the initiation of SHLH by these two closely succeeding viral primary infections. Unfortunately, histopathological investigation of bone marrow and spleen, as suggested in the diagnostic guidelines used in the HLH-2004 trial, ${ }^{13}$ could not be performed because the relatives denied further postmortem investigations. Nevertheless, regarding the clinical, laboratory and histopathological findings, five out of the eight diagnostic criteria defined by the Histiocyte Society ${ }^{1}$ were fulfilled. With the considerably elevated level of soluble CD25 (sCD25) retrospectively detected in the serum sample of day 6 (table 1), a sixth diagnostic criterion was fulfilled which further supported the diagnosis of SHLH.

\section{OUTCOME AND FOLLOW-UP}

In summary, laboratory, virological and pathological findings together with the clinical presentation suggest multiorgan failure due to SHLH initiated by EBV and closely succeeding HSV1 primary infection in a previously healthy young person.

\section{DISCUSSION}

Systemic immune dysregulation triggered by an external agent has been described as a cause of a disease continuum including HLH, sepsis, multiple organ dysfunction syndrome and systemic hyperinflammatory syndrome. ${ }^{13}$ Here we report a case of

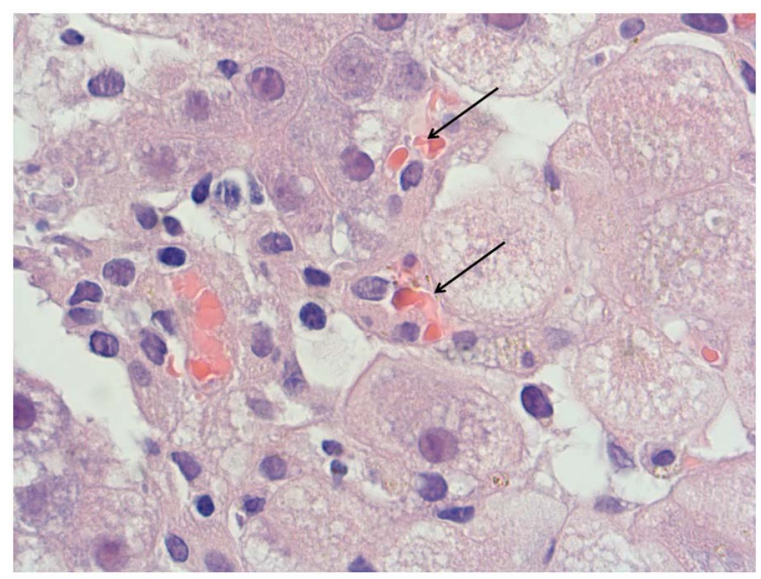

Figure 2 Acute hepatitis: haemophagocytosis with trapped erythrocytes in activated Kupffer cells (arrows), besides many inflammatory infiltrates and damaged hepatocytes (H\&E staining, $\times 500)$. foudroyant immune dysregulation following closely succeeding viral primary infections with EBV and HSV1. Clinical findings (fever, splenomegaly), laboratory parameters (cytopenia in two blood cell lines, elevated ferritin and SCD25) and haemophagocytosis in liver tissue suggest the diagnosis of SHLH based on the HLH-2004 criteria. ${ }^{13}$ In our patient serological findings indicated that primary EBV infection preceded primary HSV infection. The impairment of the immune response caused by primary EBV infection, especially the suppression of the T-cell function, may have enabled the vicious course of primary HSV1 infection in a previously healthy young adult, and both the viruses may have been subsequent triggers for the hyperinflammatory syndrome. ${ }^{3} 13$

Viral infections have been reported as common triggers of SHLH, ${ }^{1}{ }^{2}$ and the possible synergistic effects of two viral infections in the initiation of SHLH have been described in a previous report of SHLH after the close occurrence of EBV and Hepatitis A infection. ${ }^{14}$ SHLH after EBV or HSV1 infection has been described previously, and also induction of SHLH by coinfection with EBV and HSV1 has been observed before in two patients. In these cases of SHLH following EBV and HSV1 coinfection, however, EBV viraemia was due to reactivation of latent infection. ${ }^{3}$ Therefore, initiation of SHLH by primary infections with EBV and HSV1 seems to represent a unique feature of our case.

Diagnosing HLH or SHLH as defined by the Histiocyte Society ${ }^{1}$ is challenging because of its rare occurrence, variable presentation and non-specific findings and should be suspected routinely in patients with unexplained multiorgan failure. ${ }^{2} 1213$ Early diagnosis and appropriate treatment including supportive intensive care, elimination of the triggers and suppression of the inflammatory response are essential to improve the outcome of this syndrome. ${ }^{13}$ Our case highlights that in a patient with unexplained fever and elevated liver function tests, HSV in addition to EBV and cytomegalovirus (CMV) should be taken into consideration as causative agent. As reported before, the absence of mucocutaneous lesions-which initially was the case in our patient-does not exclude HSV hepatitis.

Owing to the rapid and malignant course of the disease in our patient, the diagnosis of SHLH could only be established retrospectively. Although the severe immune dysregulation may have been untreatable already on initial admission, we would like to emphasise that a delay in diagnosis and initiation of specific antiviral therapy and immunosuppressive treatment in addition to supportive intensive care may have contributed to the poor outcome. ${ }^{7} 13$

\section{Learning points}

- Primary infection with two different herpes viruses may occur simultaneously or in close succession, adversely affecting the course of the disease.

- Herpes simplex virus (HSV) and Epstein-Barr virus (EBV) should be considered in the differential diagnosis of fulminant hepatitis.

- Early virological diagnosis and immediate initiation of specific antiviral therapy is of high importance.

- EBV and HSV may cause severe disease in immunocompetent persons and secondary haemophagocytic lymphohistiocytosis should be suspected routinely when severe systemic illness develops. 
Acknowledgements The authors thank Professor Ingrid Simonitsch-Klupp (Institute of Clinical Pathology, Medical University of Vienna) for pathological investigations and Professor Winfried Pickl and Doris Trapin, MSc (Institute for Immunology, Medical University of Vienna) for carrying out the SCD25 assay.

Contributors $\mathrm{CH}$ is responsible for acquisition of patient data, study of literature, virological diagnosis, analysis and interpretation of findings and creating the manuscript. SB is responsible for access to medical history, critical discussion and revision. JT is responsible for access to medical history, critical discussion and revision. HPD is responsible for pathological examination of the liver, photographic documentation (Figure $1 A-D$ ), discussion of the case and critical review of the manuscript.

Competing interests None declared.

Patient consent Not obtained.

Provenance and peer review Not commissioned; externally peer reviewed.

Open Access This is an Open Access article distributed in accordance with the Creative Commons Attribution Non Commercial (CC BY-NC 4.0) license, which permits others to distribute, remix, adapt, build upon this work non-commercially, and license their derivative works on different terms, provided the original work is properly cited and the use is non-commercial. See: http://creativecommons.org/ licenses/by-nc/4.0/

\section{REFERENCES}

1 George MR. Hemophagocytic lymphohistiocytosis: review of etiologies and management. J Blood Med 2014;5:69-86.

2 Jordan MB, Allen CE, Weitzman S, et al. How I treat hemophagocytic lymphohistiocytosis. Blood 2011;118:4041-52.
3 Chen J, Wang $\mathrm{X}$, He P, et al. Viral etiology, clinical and laboratory features of adult hemophagocytic lymphohistiocytosis. J Med Virol 2016;88:541-9

4 Hashemi-Sadraei N, Vejpongsa P, Baljevic M, et al. Epstein-Barr virus-related hemophagocytic lymphohistiocytosis: hematologic emergency in the critical care setting. Case Rep Hematol 2015;2015:491567.

5 Sato $\mathrm{S}$, Kawashima H, Oshiro H, et al. Virological and immunological characteristics of a 19-year-old Japanese female with fatal outcome with Epstein-Barr virus-associated hemophagocytic syndrome. J Clin Virol 2004;31:235-8

6 Suzuki N, Morimoto A, Ohga S, et al. Characteristics of hemophagocytic lymphohistiocytosis in neonates: a nationwide survey in Japan. J Pediatr 2009;155:235-8 e1.

7 Rimawi BH, Meserve J, Rimawi RH, et al. Disseminated herpes simplex virus with fulminant hepatitis. Case Reports Hepatol 2015;2015:463825.

8 Riediger C, Sauer P, Matevossian E, et al. Herpes simplex virus sepsis and acute liver failure. Clin Transplant 2009;23(Suppl 21):37-41.

9 Kaufman B, Gandhi SA, Louie E, et al. Herpes simplex virus hepatitis: case report and review. Clin Infect Dis 1997;24:334-8.

10 Okano M, Gross TG. Acute or chronic life-threatening diseases associated with Epstein-Barr virus infection. Am J Med Sci 2012;343:483-9.

11 Devereaux CE, Bemiller T, Brann O. Ascites and severe hepatitis complicating Epstein-Barr infection. Am J Gastroenterol 1999;94:236-40.

12 Drori A, Ribak Y, van Heerden PV, et al. Hemophagocytic lymphohistiocytosis due to acute primary herpes simplex virus 1 infection. J Clin Virol 2015;68:6-10.

13 Ramos-Casals M, Brito-Zeron P, Lopez-Guillermo A, et al. Adult haemophagocytic syndrome. Lancet 2014;383:1503-16.

14 Pinto-Patarroyo GP, Rytting ME, Vierling JM, et al. Haemophagocytic lymphohistiocytosis presenting as liver failure following Epstein-Barr and prior hepatitis A infections. BMJ Case Rep 2013;2013.

Copyright 2017 BMJ Publishing Group. All rights reserved. For permission to reuse any of this content visit http://group.bmj.com/group/rights-licensing/permissions.

BMJ Case Report Fellows may re-use this article for personal use and teaching without any further permission.

Become a Fellow of BMJ Case Reports today and you can:

- Submit as many cases as you like

- Enjoy fast sympathetic peer review and rapid publication of accepted articles

- Access all the published articles

- Re-use any of the published material for personal use and teaching without further permission

For information on Institutional Fellowships contact consortiasales@bmjgroup.com

Visit casereports.bmj.com for more articles like this and to become a Fellow 